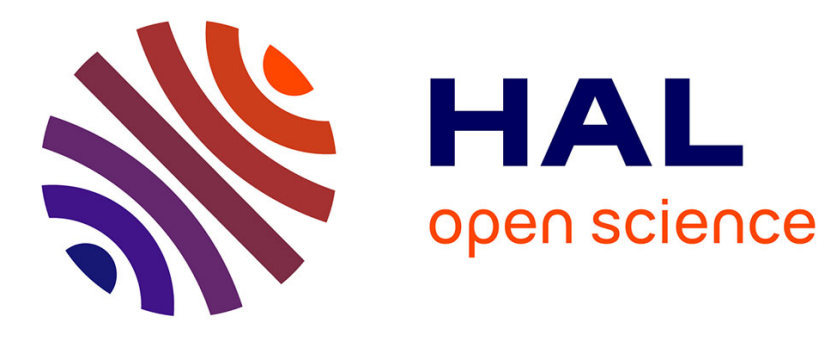

\title{
Effects of termite foraging activity on topsoil physical properties and water infiltration in Vertisol
}

\author{
Sougueh Cheik, Nicolas Bottinelli, Benoit Soudan, Ajay Harit, Ekta
}

Chaudhary, Raman Sukumar, Pascal Jouquet

\section{- To cite this version:}

Sougueh Cheik, Nicolas Bottinelli, Benoit Soudan, Ajay Harit, Ekta Chaudhary, et al.. Effects of termite foraging activity on topsoil physical properties and water infiltration in Vertisol. Applied Soil Ecology, 2019, 133, pp.132-137. 10.1016/j.apsoil.2018.10.001 . hal-01992043

\section{HAL Id: hal-01992043 \\ https://hal.sorbonne-universite.fr/hal-01992043}

Submitted on 28 Jan 2019

HAL is a multi-disciplinary open access archive for the deposit and dissemination of scientific research documents, whether they are published or not. The documents may come from teaching and research institutions in France or abroad, or from public or private research centers.
L'archive ouverte pluridisciplinaire HAL, est destinée au dépôt et à la diffusion de documents scientifiques de niveau recherche, publiés ou non, émanant des établissements d'enseignement et de recherche français ou étrangers, des laboratoires publics ou privés. 


\title{
Effects of termite foraging activity on topsoil physical properties and water infiltration in Vertisol
}

\author{
Sougueh Cheik ${ }^{\mathrm{a}, \mathrm{b}, *}$, Nicolas Bottinelli ${ }^{\mathrm{b}, \mathrm{c}}$, Benoit Soudan ${ }^{\mathrm{a}}$, Ajay Harit ${ }^{\mathrm{d}}$, Ekta Chaudhary ${ }^{\mathrm{e}}$, \\ Raman Sukumare, Pascal Jouquet ${ }^{\mathrm{a}, \mathrm{b}}$ \\ a Indo-French Cell for Water Science (IFCWS), Civil Engineering Department, Indian Institute of Science, 560012 Bangalore, Karnataka, India \\ ${ }^{\mathrm{b}}$ Institute of Ecology and Environmental Sciences (UMR 242 iEES-Paris), Sorbonne Universités, Centre IRD, Bondy, France \\ ${ }^{\mathrm{c}}$ Soils and Fertilizers Research Institute (SFRI), Dong Ngac, Tu Liem, Ha Noi, Viet Nam \\ d School of Environmental Sciences, Mahatma Gandhi University, Kottayam, Kerala, India \\ ${ }^{\mathrm{e}}$ Centre for Ecological Sciences, Indian Institute of Science, Bangalore, Karnataka, India
}

\begin{tabular}{|c|c|}
\hline & A B S T R A C T \\
\hline $\begin{array}{l}\text { Keywords: } \\
\text { India } \\
\text { Termites } \\
\text { Odontotermes spp. } \\
\text { Vertisol } \\
\text { Bioturbation } \\
\text { Soil physical properties } \\
\text { Galleries } \\
\text { Saturated hydraulic conductivity }\end{array}$ & $\begin{array}{l}\text { In the tropics, termites are key litter decomposers and soil bioturbators. Termite foraging activity involves the } \\
\text { production of sheetings and galleries that influence the physical, chemical and hydraulic properties of soils. The } \\
\text { functional impacts of these biogenic structures and biopores have been acknowledged for a long time in soils } \\
\text { dominated by } 1: 1 \text { minerals. Less is known, however, on their functional impacts in soils dominated by } 2: 1 \\
\text { minerals, such as vertisol which represent } 22 \% \text { of the land surface in India. Therefore, an experiment was carried } \\
\text { out in a vertisol in southern India where elephant (Elephas maximus) dung pats (ED) and Lantana camara twigs } \\
\text { (LT) were applied on the ground and protected ( }+ \text { ) or not ( }- \text { ) from termite activity. Termite activity was only } \\
\text { measured below ED -, showing a clear preference for organic matter derived from elephant dung. Soil sheetings } \\
\text { had similar properties to the surrounding topsoil, with the exception of their C content that was reduced. This } \\
\text { result raised the question of the origin of the soil used by termites for covering ED. ED - was also associated with } \\
\text { the presence of effective macropores up to } 5 \text { cm depth and a significant increase in water hydraulic conductivity } \\
\text { (12-fold). However, the utilization of the coefficient of linear extensibility showed that these galleries were } \\
\text { unstable and most likely short-lived. In conclusion, this study confirmed that the structure of soils dominated by } \\
2: 1 \text { minerals is mainly controlled by physical processes (i.e., the shrinking and swelling of soils). This study also } \\
\text { stresses the need to better understand the dynamic of termite galleries in soil and to quantify the origin and fate } \\
\text { of organic matter in soil sheetings. }\end{array}$ \\
\hline
\end{tabular}

\section{Introduction}

Fungus-growing termites are amongst the most important litter decomposers and soil bioturbators in arid and semi-arid environments (Bignell and Eggleton, 2000; Bottinelli et al., 2015). As "intended engineers" (sensu Jouquet et al., 2006), they build important and complex nest structures (i.e., mounds or termitaria) that protect colonies from predators and maintain a stable environment for the colony and their symbiotic fungus to grow (Lüscher, 1961). The functional impact of these mounds has been largely recognized (see Holt and Lepage, 2000; Jouquet et al., 2016; Khan et al., 2018 for reviews), especially in Africa where they constitute biodiversity and nutrient hot spots that increase the robustness of ecosystems (Bonachela et al., 2015).
Termites also influence ecosystem functioning through the production of subterranean galleries and sheetings to protect themselves from light, desiccation and predators while they forage (MacKay et al., 1985; Harit et al., 2017a,b; Fernandes et al., 2018). From studies carried out in sandy soils or in soils dominated by 1:1 minerals (e.g., sandy loams and Acrisol), it is usually considered that galleries constitute preferential flow paths and then increase water infiltration, reduce crust formation, water runoff and soil erosion in arid and sub-arid ecosystems (e.g., Eldridge and Pickard, 1994; Mando et al., 1996, 1999; Mando, 1997; Sarr et al., 2005; Mettrop et al., 2013; Léonard and Rajot, 2001; Léonard et al., 2004; Colloff et al., 2010: Kaiser et al., 2017). Although less known, a recent review suggests that soil sheetings are always enriched in clay in comparison with the surrounding soil but that their

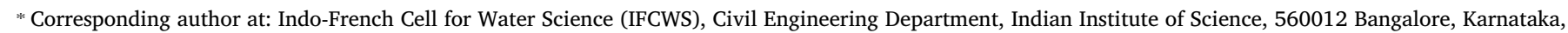
India.

E-mail address: sougueh.cheik@ird.fr (S. Cheik). 
$\mathrm{C}$ content varies depending on the $\mathrm{C}$ content of the putative parent soil (Harit et al., 2017b). Moreover, an experiment carried out in a humid tropical environment showed that the low stability of soil sheetings to water increases soil detachment, the sealing of soil surface and water runoff (Jouquet et al., 2012).

Conversely, the impact of termites on water dynamic is unknown in soils dominated by 2:1 minerals. In India, Vertisol soils occupy a large surface with 70.3 million ha, constituting $22 \%$ of the total geographical area (Mandal et al. 2013). These soils are subject to shrinkage after wetting and drying cycles, leading to the formation of physicogenic aggregates (sensu Pulleman and Marinissen, 2004; Jouquet et al., 2009) and cracks which serve as preferential pathways for rainwater. In these soils, biogenic structures are considered unstable and the ecological impact of soil fauna on soil dynamics to be non-significant or of low importance (e.g. Oades, 1993; Blanchart et al., 2004), although the question has never been addressed with termites, and especially in India. Therefore, the objective of this study was to determine how termite foraging activity impacts soil aggregation and water infiltration (i.e., through the production of sheeting and galleries) in Vertisol soils in India. Our hypothesis was that termite galleries and sheetings do not resist water, due to the swelling behavior of soils, and therefore that the influence of termite foraging activity on soil aggregate stability and water infiltration is of minor importance.

\section{Materials and methods}

\subsection{Study site}

This study was carried out in a private land situated within a dry zone of the Nilgiri Biosphere Reserve of southern India $\left(11^{\circ} 31^{\prime} 50.84^{\prime \prime} \mathrm{N}\right.$ and $76^{\circ} 38^{\prime} 37.11^{\prime \prime} \mathrm{E}$ ). With about $600 \mathrm{~mm}$ year $^{-1}$ on average, the vegetation here is described as tropical dry-thorn forest. With approx. $30 \%$ of clay dominated by $2: 1$ clays and $4.5 \%$ of $C$ in the $0-20 \mathrm{~cm}$ soil layer, the soil is described as Vertisol in the US Soil Taxonomy (USDA) and FAO classifications (Soil Survey Staff, 2014). In this environment, soil bioturbation mainly results from the activity of fungus-growing termites, mainly Odontotermes obesus and $O$. redemanni.

\subsection{Experimental setup}

The experiment was carried out from March to June 2016 during the dry season when the land had few herbaceous plants and low grass cover, with the exception of some patches of the invasive, woody shrub Lantana camara. The experiment consisted in the application of elephant (Elephas maximus) dung pads $(\sim 250 \mathrm{~g})$ and Lantana camara twigs and leaves $(\sim 400 \mathrm{~g})$ on the ground. Elephant dung was chosen because it is an attractive, although sporadic, resource for termites in the field (Chaudhary Ekta, pers. obs.). Lantana camara is an invasive species native to the Americas (Patel, 2011; Ramaswami and Sukumar, 2014) and constitutes an abundant but unpalatable resource of organic matter to soil detritivores because of the allelopathic chemicals it contains (Verma and Verma, 2006; Verma et al., 2009). Elephant dung pads (ED) and Lantana camara twigs (LT) were enclosed in $100 \mu \mathrm{m}$ mesh size nets $(\mathrm{ED}+, \mathrm{LT}+)$ or not $(\mathrm{ED}-, \mathrm{LT}-)$ and their impact on termite activity was compared to a control (CTRL) without organic amendment. The number of replicates (n) equaled to 5 for $\mathrm{ED}+, \mathrm{LT}+$ and $\mathrm{LT}-$ but we used $n=10$ in the case of the control and ED - . 5 replicates were used for measuring water hydraulic conductivity and soil physical and chemical properties for all the treatments and the 5 additional replicates for ED - and CTRL were used for measuring soil macroporosity after the application of methylene blue water (see below).

\subsection{Soil sheeting properties}

At the end of the experiment, soil sheeting was found on elephant dung. Sheetings were sampled and their properties analyzed and compared to the surrounding top-soil $(0-2 \mathrm{~cm}$ depth, $>1 \mathrm{~m}$ distance from the dung patch) $(\mathrm{n}=5)$. Soil $\mathrm{pH}$ and conductivity were determined in 1:5 soil: water suspension and the C content was determined with a SHIMADZU TOC $\mathrm{V}_{\mathrm{CSH}}$ analyzer (model SSM-5000A). The particle-size distribution was assessed after destruction of soil organic matter and dispersion with hydrogen peroxide and sodium hexametaphosphate. Particles were differentiated into clay $(<2 \mu \mathrm{m})$, silts $(2-50 \mu \mathrm{m})$ and sand $(50-2000 \mu \mathrm{m})$ after sieving and sedimentation. Soil aggregate stability was measured after immersion of $5 \mathrm{~g}$ of $>2 \mathrm{~mm}$ soil aggregates in $15 \mathrm{ml}$ distilled water for $5 \mathrm{~min}$. The fraction of soil $>200 \mu \mathrm{m}$ was used to measure the percentage of water stable aggregates, after correction to their sand content.

\subsection{Water infiltration and diffusion}

Soil hydraulic conductivity was measured with the Beerkan method (Haverkamp et al., 1994; Braud et al., 2005; Lassabatère et al., 2006) and using a cylinder in plastic (in polyvinyl chloride or PVC) having an inner diameter of $11 \mathrm{~cm}$. The cylinder was positioned at the soil surface and inserted to a depth of about $1 \mathrm{~cm}$. A fixed volume of water $(100 \mathrm{ml}$, corresponding to a water depth of about $1 \mathrm{~cm}$ ) was poured into the cylinder and the time needed for the water to infiltrate was measured. The procedure was repeated between 7 and 10 times for it to reach a steady state of infiltration. The undisturbed soil cores were used to determine the soil bulk density, $\rho\left(\mathrm{g} \mathrm{cm}^{-3}\right)$ and the initial volumetric water content, $\theta_{\mathrm{i}}\left(\mathrm{m}^{3} \mathrm{~cm}^{-3}\right)$, was measured after sampling the surrounding top-soil environment $(0-5 \mathrm{~cm}$ depth). Results were analyzed with the original BEST algorithm (Lassabatère et al., 2006) in order to calculate the saturated hydraulic conductivity (Ksat).

The presence of effective macropores was measured for ED and CTRL treatments using methylene blue as a dye tracer (Capowiez et al., 2009). As for the measure of Ksat, cylinders were installed at the soil surface and poured with $3 \mathrm{~cm}$ of water $(=300 \mathrm{ml})$ containing methylene blue (concentration $=0.01 \mathrm{M}$ ). After $12 \mathrm{~h}$, the soil below the PVC rings was excavated with a spade in order to prepare successive horizontal planes at $0,0.5,1,2,3,4$ and $5 \mathrm{~cm}$ depth. The surface was then photographed. The pictures were analyzed and the surface of each visible stained macropore was measured using Image $\mathrm{J}$ software.

\subsection{Below-ground soil physical and chemical properties}

The hydrostructural stability (Schäffer et al., 2008) of soil porosity was assessed from the measure of the coefficient of linear extensibility (COLE) defined by Grossman et al. (1968). Undisturbed soil samples were collected from the surface soil layer $(0-5 \mathrm{~cm})$ using cylinders (5.7 $\mathrm{cm}$ diam $\times 5 \mathrm{~cm}$ high) at each sampling location after measuring soil water infiltration rate, as described in Section 2.3. Soil samples were dried at $40^{\circ} \mathrm{C}$ for $48 \mathrm{~h}$ and then partially immersed with water until saturation by capillarity. The COLE was computed as follows:

$\operatorname{COLE}=\left(\mathrm{L}_{0}-\mathrm{L}_{105}\right) / \mathrm{L}_{105}$

where $L_{0}$ and $L_{105}$ are the height of soil cores at saturation and after oven drying at $105{ }^{\circ} \mathrm{C}$. Soils were also sampled at $1-3 \mathrm{~cm}$ depth and analyzed for total $\mathrm{C}$ and particle size distribution contents as described above. Furthermore, to estimate root biomass, each sample was placed in a beaker and soaked in water for at least $30 \mathrm{~min}$, so that soil aggregates can be easily broken down. Afterwards, the soil samples were washed through a $200 \mu \mathrm{m}$ sieve. Roots were rinsed to remove any excess of soil and weighted after drying at $60^{\circ} \mathrm{C}$ for $48 \mathrm{~h}$.

\subsection{Statistical analyses}

All statistical calculations were carried out using R and RStudio (version i386 3.2.5). The number of replicates was determined using the power.anova.test function for a power of the test equal to 0.8 . Data were balanced (equal number of observations for each factor) and the 
normal distribution of residues was tested using the Shapiro-Wilk test. One-way ANOVA was used to analyze the soil chemical and physical properties with treatments as independent variable. LSD tests were then performed to assess differences between means. T-tests were used for comparing (i) termite sheeting properties from the properties of the topsoil and (ii) the surface dyed by methylene blue for ED - and CTRL treatments for each soil depths. Multiple linear regressions were used to assess the influence of soil physical and chemical properties (C, sand, silt or clay contents, soil bulk density, root biomass, COLE) on Ksat. Finally, an analysis of covariance (ANCOVA) was used to compare the effect of the treatments (LT - and ED - vs. CTRL, LT + and ED +), as covariate, on the linear relationship between COLE and Ksat. Differences among treatments were declared significant at the $P<0.05$ probability level.

\section{Results}

\subsection{Impact of termite activity on soil physical and chemical properties}

After three months, termite activity was recorded only in ED-. Termites were identified as Odontotermes obsesus or O. redemanni. Apart from termites, no other soil macrofauna was found. Since termites were only measured in ED-, soil sheetings could only be collected for this treatment and their properties compared to the surrounding soil. Soil sheetings had the same physical and chemical properties as the topsoil (Table 1 ), with the exception of the soil C content that was significantly lower in termite sheetings than in the control $(P<0.05)$.

The influence of the different treatments on below-ground soil properties is shown in Table 2. Soil physical and chemical properties were not influenced by the different treatments $(P>0.05$ in all cases), with the exception of Ksat which was significantly higher in ED - in comparison with CTRL, LT + and ED + $(P<0.05$, Fig. 1). LT - had an intermediate Ksat value, not significantly different from ED - and CTRL, $\mathrm{LT}+$ and ED $+(P>0.05$ in all cases $)$.

\subsection{Abiotic variables explaining the evolution of Ksat in soil}

Stepwise regression shows that Ksat was linearly related to COLE and in a smaller extent to the silt content of soils (Table 2, Ksat $=0.03-0.62$ silt $(\%)+1.67$ COLE, $\left.\mathrm{R}^{2}=0.37, \mathrm{p}=0.006\right)$. Results of the ANCOVA testing the influence of COLE on Ksat with soil macrofauna activity (associated to ED - and LT - ) as covariate showed a significant difference in slope across groups $\left(F_{1,21}=13.27, P=0.001\right)$. No relationship was found between Ksat and COLE in CTRL and below substrates that were protected from soil macrofauna activity (ED + and LT +$)(P=0.550)$, while Fig. 2 shows a positive linear relationship below non-protected substrates (ED - and LT - ) $\left(\right.$ Ksat $=2.068 \times$ COLE-0.082, $\left.\mathrm{R}^{2}=0.56, P=0.012\right)$.

\subsection{Diffusion of methylene blue water in soil}

The surface of soil dyed in blue decreased with soil depth (Fig. 3). No significant differences between CTRL and ED - could be measured up to $3 \mathrm{~cm}(P>0.05$ in all cases). Methylene blue could not be measured after $3 \mathrm{~cm}$ depth for CTRL while it reached $5 \mathrm{~cm}$ depth in EDwith $\sim 3.8 \%$ of the soil dyed in blue at $5 \mathrm{~cm}$ depth $(P<0.05$ at both 4
Table 2

Results of the ANOVA testing the influence of the treatments on soil physical and chemical below-ground properties: sand, silt and clay contents, C content, Soil bulk density, root biomass, Ksat and COLE. Significant results at 0.05 are highlighted in bold characters.

\begin{tabular}{lll}
\hline & $F$ & $P$-value \\
\hline Sand & $F_{4,20}=0.216$ & 0.927 \\
Silt & $F_{4,20}=0.991$ & 0.435 \\
Clay & $F_{4,20}=0.147$ & 0.962 \\
C & $F_{4,20}=1.251$ & 0.322 \\
Soil bulk density & $F_{4,20}=0.458$ & 0.766 \\
Root biomass & $F_{4,20}=1.656$ & 0.200 \\
Ksat & $F_{4,20}=\mathbf{3 . 5 8 2}$ & $\mathbf{0 . 0 2 3}$ \\
COLE & $F_{4,20}=0.498$ & 0.737 \\
\hline
\end{tabular}

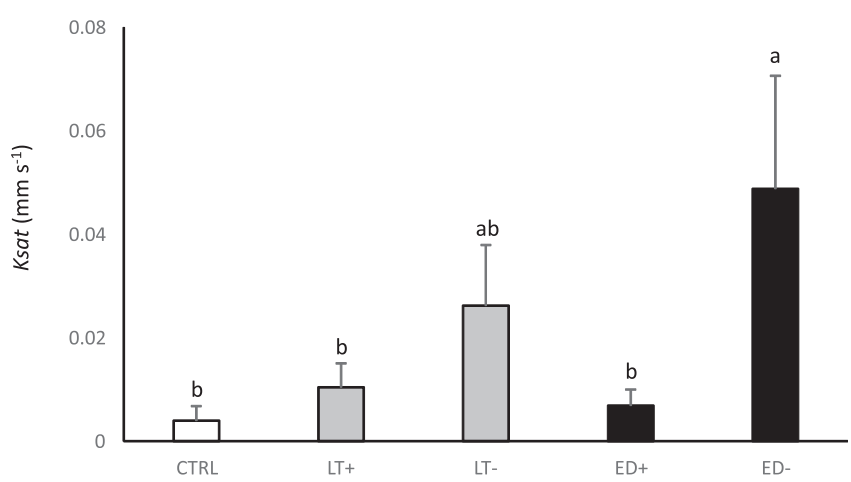

Fig. 1. Influence of the treatments on Ksat $\left(\mathrm{mm} \mathrm{s}^{-1}\right)$. Treatments are: "CTRL" for Control, "LT" for Lantana twigs and "ED" for Elephant dung, enclosed in a net $(+)$ or not $(-)$. Histograms with the same letters are not significantly different at $P \geq 0.05$ (LSD test, $\mathrm{n}=5$ ).

and $5 \mathrm{~cm}$ depth).

\section{Discussion}

\subsection{Influence of litter quality on termite activity}

The opportunistic consumption of mammalian dung by termites has been described long ago (e.g., Ferrar and Watson, 1970; Freymann et al., 2008). In our case, elephant dung piles were rapidly detected by termites and their consumption was associated to the presence of soil sheetings. Although no sheeting was found on Lantana camara, intermediate Ksat values were measured in LT - in comparison with ED and CTRL or LT + . Therefore, these results suggest that LT - was associated with the presence of macropores in soils, even if they were not consumed by termites. No other soil decomposer was observed in our study site but our experiment did not allow rejecting the hypothesis that LT - also favored the activity of other soil burrowers (e.g., diplopods, ants) during the 3 months of the experiment. However, we consider that this hypothesis is unlikely because of the dryness of the soil during the dry season and because no ants or diplopods were measured in ED - and LT - at the end of the experiment. Therefore, we assume that termites were initially attracted by the availability of Lantana camara on the ground and then produced soil galleries reaching these

Table 1

Soil physical and chemical properties (pH, electrical conductivity $\left(\mu \mathrm{S} \mathrm{cm}^{-1}\right), \mathrm{C}$, sand, silt and clay contents (\%), soil aggregate stability (\%)) in termite sheeting and their surrounding topsoil environment. Values in parentheses are standard errors $(\mathrm{SE}, \mathrm{n}=5) . P$-values were considered significant at 0.05 and derived from T-tests.

\begin{tabular}{|c|c|c|c|c|c|c|c|}
\hline & $\mathrm{pH}$ & $\mathrm{EC}\left(\mu \mathrm{S} \mathrm{cm}{ }^{-1}\right)$ & C (\%) & Sand (\%) & Silt (\%) & Clay (\%) & Stable aggregates $>200 \mu \mathrm{m}(\%)$ \\
\hline Control & $7.13(0.28)$ & $130.54(29.84)$ & $4.48(0.44)$ & $51.52(2.46)$ & $22.20(1.84)$ & $24.89(0.63)$ & $60.32(12.63)$ \\
\hline Termite sheeting & $6.53(0.30)$ & $84.10(11.74)$ & $1.98(0.43)$ & $51.24(4.08)$ & $20.64(2.48)$ & $28.13(3.85)$ & $73.41(5.91)$ \\
\hline$P$-values & 0.179 & 0.205 & 0.003 & 0.954 & 0.629 & 0.456 & 0.386 \\
\hline
\end{tabular}




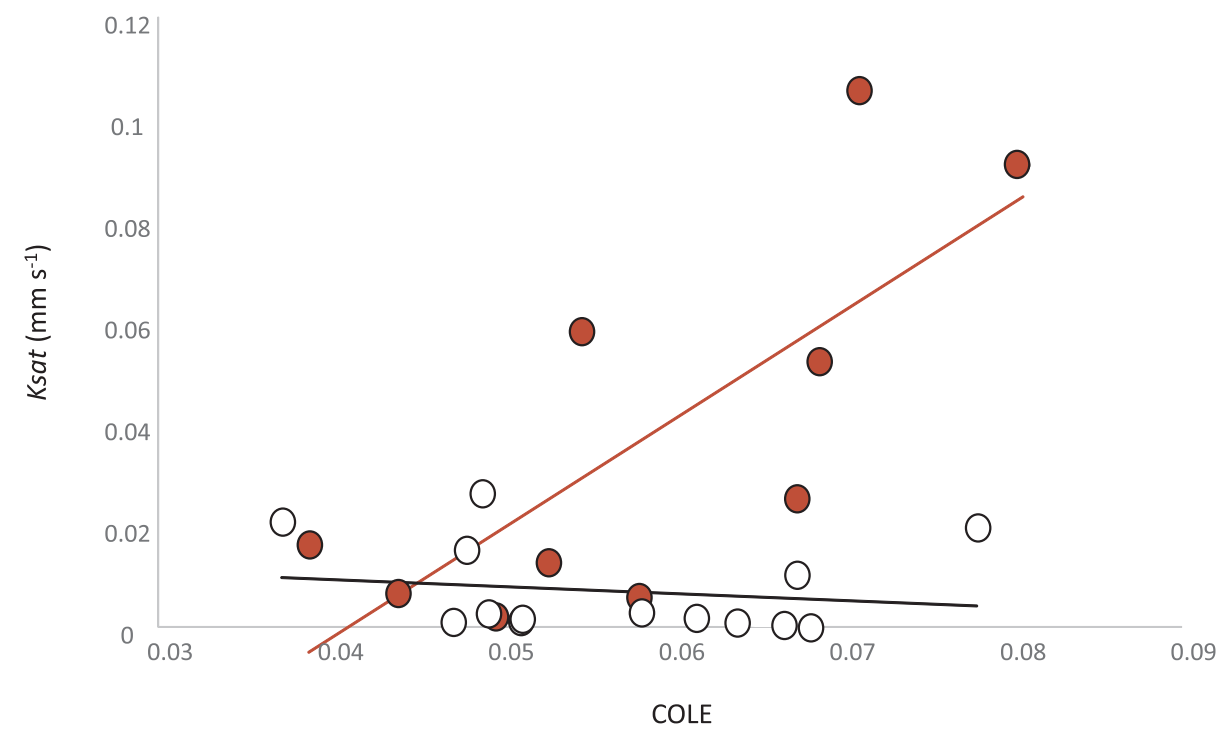

Fig. 2. Relationship between COLE and Ksat (mm $\mathrm{s}^{-1}$ ) for the soils impacted (ED - and LT - , in red) and not impacted by soil macrofauna activity (CTRL, $\mathrm{ED}+$ and $\mathrm{LT}+$, in white). Linear regressions are given, $\mathrm{n}=10$ for impacted plots (in filled dots) and $\mathrm{n}=15$ for not impacted plots (in white). (For interpretation of the references to colour in this figure legend, the reader is referred to the web version of this article.)

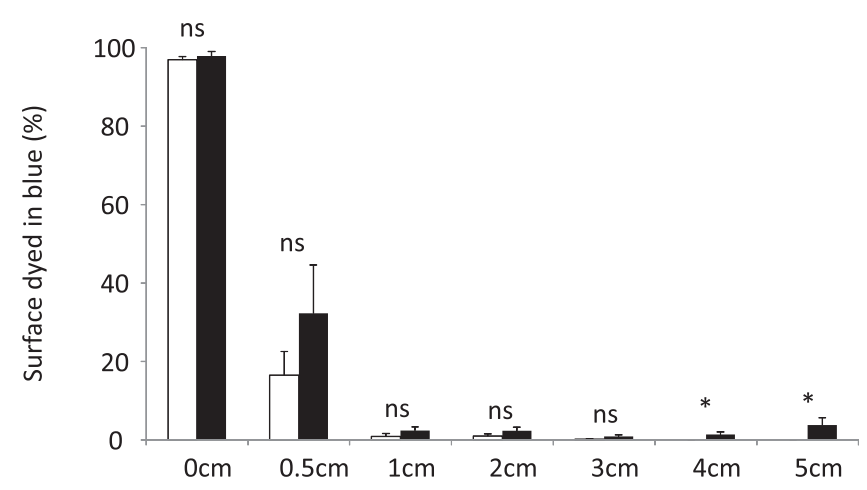

Fig. 3. Surface of the soil dyed with methylene blue water (in \%) for different soil depths $(0,0.5,1,2,3,4$ and $5 \mathrm{~cm})$ and for the control soil (in white) and below ED - (in black), $\mathrm{n}=5$. "ns" for non significant and * for $P<0.05$. (For interpretation of the references to colour in this figure legend, the reader is referred to the web version of this article.)

substrates. However, the production of galleries remained limited because Lantana camara was not consumed by termites, mainly because of its repellent properties (Verma et al., 2009; Ding and Hu, 2010; Yuan and $\mathrm{Hu}, 2012$ ). Consequently, it can be concluded from this experiment that elephant dung is a sporadic, unpredictable but effective resource for termites and might be preferred to Lantana camara, which is an abundant but unattractive resource, if the aim is to stimulate termite foraging activity in the field.

\subsection{Bioturbation by termites and soil sheeting properties}

Termite foraging activity is associated with the production of soil sheetings. Our study shows that these biogenic structures had similar properties than the surrounding topsoil, with the exception of their $\mathrm{C}$ content. The similar particle size distribution between sheetings and their surrounding topsoil can be explained by the relatively homogeneous organization of the upper half meter of Vertisols (Sehgal, 2012), with the exception of the soil C content that can reach $>5 \%$ in the first few $\mathrm{cm}$ and can drop to a few \% in deeper soil layers. For instance, $20 \mathrm{~km}$ way from our study site, Jouquet et al. (2017) found a C content of $3.5 \%$ in the $0-5 \mathrm{~cm}$ soil layer of a Vertisol and $1.22 \%$ in their $30-70 \mathrm{~cm}$ soil layer. In our study, the lower C content in sheeting suggests that they were not made of soil collected in the topsoil but rather below $30 \mathrm{~cm}$ depth. Although more research is clearly needed to confirm our results in other soil pedological contexts, we consider that termite foraging activity is likely to be associated with a modification of C dynamics in soil, with the translocation of potentially old organic matter from deep soil layers to the surface. This hypothesis does not confirm the results of Diouf et al. (2006) and Villenave et al. (2009) who concluded that sheetings made by fungus-growing termites are produced by translocating soil from the superficial strata $(0-3 \mathrm{~cm})$ to the surface in African savannas. However, they are in line with the results of Harit et al. (2017b) who showed that sheetings are enriched in $C$ when the surrounding topsoil has a low $C$ concentration $(<1 \%)$ while they are impoverished in $\mathrm{C}$ when the surrounding topsoil has $\mathrm{C}$ content $>1 \%$. Finally, despite lower $\mathrm{C}$ content, soil sheetings were as stable as topsoil aggregates, thus confirming the limited impact of soil macrofauna on soil aggregation in vertisol (Oades, 1993; Blanchart et al., 2004).

\subsection{Impact of termites on soil porosity and water dynamic}

In structured soils, macropores can act as preferential flow paths (Beven and Germann, 1982) when they are disconnected from other pores. In our case, termite preference for elephant dung was associated with the production of belowground galleries that increased Ksat. This finding confirms previous studies carried out in West Africa that showed a positive impact of termite foraging activity on soil water infiltration (Mando et al., 1996, 1999; Léonard et al., 2004), although other studies concluded about a non-significant or negative impact (Mando et al., 1999; Mettrop et al., 2013). In our experiment, Ksat was increased by approximately 12 -fold in comparison with the control soil $\left(0.049\right.$ vs. $\left.0.004 \mathrm{~mm} \mathrm{~s}^{-1}\right)$. This result is in line with the findings of Mando and van Rheenen (1998) (10.5-fold) or Kaiser et al. (2017) (1.5-9.28-fold), although termite foraging activity is usually only increased by only 1.5-3-fold (Elkins et al., 1986; Mando et al., 1996, 1999; Léonard and Rajot, 2001).

In Sahel, Léonard and Rajot (2001) found that galleries made by Odontotermes sp. are mainly superficial and horizontal within the first $\mathrm{cm}$ of soil. In our study, results from the methylene blue method did not allow us to show a beneficial impact of termites on the first $\mathrm{cm}$ of soil but rather suggest a presence of galleries beyond $3 \mathrm{~cm}$ of depth. Consequently, this suggests that termites preferred building galleries in deeper soil layers than in Sahelian environment and/or that superficial galleries are unstable and rapidly degraded while galleries built in depth are less susceptible to crack formation. Indeed, higher COLE was measured with the presence of termite activity, whereas clay content was similar. This indicated that termite burrows were less stable than other types of pores during soil drying, confirming therefore our 
hypothesis that few or no burrows can be found close to the surface because of their low hydrostructural stability.

\section{Conclusion}

This study confirms the general assumption that soil fauna has a limited impact on the dynamic of soil structure in soils dominated by 2:1 minerals. Soil sheetings were very similar in their properties to the surrounding topsoil, with the exception of the C content. However, their lower $\mathrm{C}$ content raised the question of the origin of the soil used by termites for building their sheetings. More research is also clearly needed to determine the dynamics of the $\mathrm{C}$ contained in soil sheetings, especially if it comes from a deeper and older SOM pool. Termite foraging activity is also associated with the production of galleries which temporarily increase soil water hydraulic conductivity. However, the results of this study raise the question of the resistance of these biopores to shrinking-swelling cycles, which are characteristic of soils dominated by 2:1 minerals. We suggest that the lifetime and durability of these galleries represent some important topics that require more research to develop a complete understanding of the influence of termites on the dynamic of soil structure.

\section{Acknowledgments}

We would like to thank Prof. S. Subramanian and J. Riotte for their supports and for allowing us to have access to facilities from IISc. We also thank the Editor an the two anonymous reviewers for their useful suggestions on the draft script. Raman Sukumar was a JC Bose National Fellow during the tenure of the study. This project was supported by the French National Program EC2CO-Biohefect "MACROFLUX" and also benefited from funding from the Indo-French Cell for Water Science (LMI CEFIRSE, http://www.cefirse.ird.fr).

\section{References}

Beven, K., Germann, P., 1982. Macropores and water flow in soils. Water Resour. Res. 18, 1311-1325. https://doi.org/10.1029/WR018i005p01311.

Bignell, D.E., Eggleton, P., 2000. Termites in ecosystems. In: Termites: evolution, sociality, symbioses, ecology. Springer, Dordrecht, pp. 363-387 10.1007/978-94-0173223-9 17.

Blanchart, E., Albrecht, A., Brown, G., Decaens, T., Duboisset, A., Lavelle, P., Roose, E., 2004. Effects of tropical endogeic earthworms on soil erosion. Agric. Ecosyst. Environ. 104, 303-315. https://doi.org/10.1016/j.agee.2004.01.031.

Bonachela, J.A., Pringle, R.M., Sheffer, E., Coverdale, T.C., Guyton, J.A., Caylor, K.K., Levin, S.A., Tarnita, C.E., 2015. Termite mounds can increase the robustness of dryland ecosystems to climatic change. Science 347, 651-655. https://doi.org/10. 1126/science.1261487.

Bottinelli, N., Jouquet, P., Capowiez, Y., Podwojewski, P., Grimaldi, M., Peng, X., 2015. Why is the influence of soil macrofauna on soil structure only considered by soil ecologists? Soil Till Res. 146, 118-124. https://doi.org/10.1016/j.still.2014.01.007.

Braud, I., De Condappa, D., Soria, J.M., Haverkamp, R., Angulo-Jaramillo, R., Galle, S., Vauclin, M., 2005. Use of scaled forms of the infiltration equation for the estimation of unsaturated soil hydraulic properties (the Beerkan method). Eur. J. Soil Sci. 56, 361-374. https://doi.org/10.1111/j.1365-2389.2004.00660.x.

Capowiez, Y., Cadoux, S., Bouchant, P., Ruy, S., Roger-Estrade, J., Richard, G., Boizard, H., 2009. The effect of tillage type and cropping system on earthworm communities, macroporosity and water infiltration. Soil Till. Res. 105, 209-216. https://doi.org/ 10.1016/j.still.2009.09.002.

Colloff, M.J., Pullen, K.R., Cunningham, S.A., 2010. Restoration of an ecosystem function to revegetation communities; the role of invertebrate macropores in enhancing soil water infiltration. Rest. Ecol. 18, 65-72. https://doi.org/10.1111/j.1526-100X.2010. 00667.x.

Ding, W., Hu, X.P., 2010. Antitermitic effect of the Lantana camara plant on subterranean termites (Isoptera: Rhinotermitidae). Insect Sci. 17, 427-433. https://doi.org/10. 1111/j.1744-7917.2010.01326.x.

Diouf, M., Miambi, E., Mora, P., Delgarde, S., Rouland, C., 2006. The impact of termite sheetings age on their fungal communities. Eur. J. Soil Biol. 42, S85-S91. https://doi. org /10.1016/j.ejsobi.2006.07.003.

Eldridge, D.J., Pickard, J., 1994. Effects of ants on sandy soils in semi-arid eastern Australia. 2. Relocation of nest entrances and consequences for bioturbation. Soil Res. 32, 323-333. https://doi.org/10.1071/SR9940323.

Elkins, N.Z., Sabol, G.V., Ward, T.J., Whitford, W.G., 1986. The influence of subterranean termites on the hydrological characteristics of a Chihuahuan desert ecosystem. Oecologia 68, 521-528. https://doi.org/10.1007/BF00378766.

Fernandes, G.W., Murcia, S.L., Santos, J.C., DeSouza, O., Constantino, R., Haifig, I., 2018.
Termite foraging on plants of a brazilian savanna: the effects of tree height. Sociobiol. 65, 48-58. https://doi.org/10.13102/sociobiology.v65i1.1802.

Ferrar, P., Watson, J.A.L., 1970. Termites (Isoptera) associated with dung in Australia Austral Entomol. 9, 100-102. https://doi.org/10.1111/j.1440-6055.1970.tb00778.x.

Freymann, B.P., Buitenwerf, R., Desouza, O., Olff, H., 2008. The importance of termites (Isoptera) for the recycling of herbivore dung in tropical ecosystems: a review. Eur. J. Entomol. 105, 165. https://doi.org/10.14411/eje.2008.025.

Grossman, R.B., Brasher, B.R., Franzmeier, D.P., Walker, J.L., 1968. Linear extensibility as calculated from natural-clod bulk density measurements 1. Soil Sci. Soc. Am. J. 32, 570-573. https://doi.org/10.2136/sssaj1968.03615995003200040041x.

Harit, A., Moger, H., Duprey, J.L., Abbasi, S.A., Subramanian, S., Jouquet, P., 2017a. Termites can have greater influence on soil properties through the construction of soil sheetings than the production of above-ground mounds. Insectes Soc. 67, 247-253. https://doi.org/10.1007/s00040-017-0541-3.

Harit, A., Shanbhag, R., Chaudhary, E., Cheik, S., Jouquet, P., 2017b. Properties and functional impact of termite sheetings. Biol. Fertil. Soils 53, 743-749. https://doi. org/10.1007/s00040-017-0541-3.

Haverkamp, R., Ross, P.J., Smettem, K.R.J., Parlange, J.Y., 1994. Three-dimensional analysis of infiltration from the disc infiltrometer: 2. Physically based infiltration equation. Water Resour. Res. 30, 2931-2935. https://doi.org/10.1029/94WR01788.

Holt, J.A., Lepage, M., 2000. Termites and soil properties. In: Abe, T., Bignell, D.E., Higashi, M. (Eds.), Termites: evolution, sociality, symbioses, ecology. Springer, Dordrecht, pp. 389-407. https://doi.org/10.1007/978-94-017-3223-9_18.

Jouquet, P., Dauber, J., Lagerlöf, J., Lavelle, P., Lepage, M., 2006. Soil invertebrates as ecosystem engineers: intended and accidental effects on soil and feedback loops. Appl. Soil Ecol. 32, 153-164. https://doi.org/10.1016/j.apsoil.2005.07.004.

Jouquet, P., Zangerlé, A., Rumpel, C., Brunet, D., Bottinelli, N., Tran Duc, T., 2009. Relevance and limitations of biogenic and physicogenic classification: a comparison of approaches for differentiating the origin of soil aggregates. Eur. J. Soil Sci. 60, 1117-1125. https://doi.org/10.1111/j.1365-2389.2009.01168.x.

Jouquet, P., Janeau, J.L., Pisano, A., Sy, H.T., Orange, D., Minh, L.T.N., Valentin, C., 2012. Influence of earthworms and termites on runoff and erosion in a tropical steep slope fallow in Vietnam: a rainfall simulation experiment. Appl. Soil Ecol. 61, 161-168. https://doi.org/10.1016/j.apsoil.2012.04.004.

Jouquet, P., Bottinelli, N., Shanbhag, R.R., Bourguignon, T., Traoré, S., Abbasi, S.A., 2016. Termites: The neglected soil engineers of tropical soils. Soil Sci. 181, 157-165. https://doi.org/10.1097/ss.0000000000000119.

Jouquet, P., Airola, E., Guilleux, N., Harit, A., Chaudhary, E., Grellier, S., Riotte, J., 2017. Abundance and impact on soil properties of cathedral and lenticular termite mounds in Southern Indian woodlands. Ecosystems 20, 769-780. https://doi.org/10.1007/ s10021-016-0060-5.

Kaiser, D., Lepage, M., Konaté, S., Linsenmair, K.E., 2017. Ecosystem services of termites (Blattoidea: Termitoidae) in the traditional soil restoration and cropping system Zai in northern Burkina Faso (West Africa). Agr. Ecosyst Environ. 236, 198-211. https:// doi.org/10.1016/j.agee.2016.11.023.

Khan, M.A., Ahmad, W., Paul, B., 2018. Ecological Impacts of Termites. In: Khan, A., Ahmad, W. (Eds.), Termites and Sustainable Management. Springer, pp. 201-216.

Lassabatère, L., Angulo-Jaramillo, R., Soria Ugalde, J.M., Cuenca, R., Braud, I., Haverkamp, R., 2006. Beerkan estimation of soil transfer parameters through infiltration experiments - BEST. Soil Sci. Soc. Am. J. 70, 521-532. https://doi.org/10. 2136/sssaj2005.0026.

Léonard, J., Rajot, J.L., 2001. Influence of termites on runoff and infiltration: quantification and analysis. Geoderma 104, 17-40. https://doi.org/10.1016/S00167061(01)00054-4.

Léonard, J., Perrier, E., Rajot, J.L., 2004. Biological macropores effect on runoff and infiltration: a combined experimental and modelling approach. Agr. Ecosyst. Environ. 104, 277-285. https://doi.org/10.1016/j.agee.2003.11.015.

Lüscher, M., 1961. Air-conditioned termite nests. Sci. Am. 205, 138-147.

Mackay, W.P., Blizzard, J.H., Miller, J.J., Whitford, W.G., 1985. Analysis of above-ground gallery construction by the subterranean termite Gnathamitermes tubiformans (Isoptera: Termitidae). Environ. Entomol. 14, 470-474. https://doi.org/10.1093/ee/ 14.4.470.

Mandal, K.G., Hati, K.M., Misra, A.K., Bandyopadhyay, K.K., Tripathi, A.K., 2013. Land surface modification and crop diversification for enhancing productivity of a Vertisol. Int. J. Plant Prod. 7, 455-472. https://doi.org/10.22069/IJPP.2013.1114.

Mando, A., Van Rheenen, T., 1998. Termites and agricultural production in the Sahel: from enemy to friend? NJAS Wageningen J. Life Sci. 46, 77-85.

Mando, A., Stroosnijder, L., Brussaar, L., 1996. Effects of termites on infiltration into crusted soil. Geoderma 74, 107-113. https://doi.org/10.1016/S0016-7061(96) 00058-4.

Mando, A., Brussaard, L., Stroosnijder, L., 1999. Termite-and mulch-mediated rehabilitation of vegetation on crusted soil in West Africa. Restor. Ecol. 7, 33-41. https://doi.org/10.1046/j.1526-100X.1999.07104.x.

Mando, A., 1997. The impact of termites and mulch on the water balance of crusted Sahelian soil. Soil Techn. 11, 121-138. https://doi.org/10.1016/S0933-3630(97) 00003-2.

Mettrop, I.S., Cammeraat, L.H., Verbeeten, E., 2013. The impact of subterranean termite activity on water infiltration and topsoil properties in Burkina Faso. Ecohydrology 6, 324-331. https://doi.org/10.1002/eco.1271.

Oades, J.M., 1993. The role of biology in the formation, stabilization and degradation of soil structure. Soil Struct./Soil Biota Interrelationships 377-400. https://doi.org/10 1016/B978-0-444-81490-6.50033-9.

Patel, S., 2011. A weed with multiple utility: Lantana camara. Rev. Environ. Sci. Bio/ Technol. 10, 341-351. https://doi.org/10.1007/s11157-011-9254-7.

Pulleman, M.M., Marinissen, J.C.Y., 2004. Physical protection of mineralizable C in aggregates from long-term pasture and arable soil. Geoderma 120, 273-282. https:// 
doi.org/10.1016/j.geoderma.2003.09.009.

Ramaswami, G., Sukumar, R., 2014. Lantana camara L. (Verbenaceae) invasion along streams in a heterogeneous landscape. J. Biosci. 39, 717-726. https://doi.org/10. 1007/s12038-014-9465-5.

Sarr, M., Maniania, N.K., Russell-Smith, A., Niassy, A., 2005. Diversité des termites (Isoptera) au Sénégal et leurs dégâts sur les cultures et périmètres reboisés. Int. J. Trop. Insect. Sci. 25, 147-158. https://doi.org/10.1079/IJT200575.

Schäffer, B., Mueller, T.L., Stauber, M., Müller, R., Keller, M., Schulin, R., 2008. Soil and macro-pores under uniaxial compression. II. Morphometric analysis of macro-pore stability in undisturbed and repacked soil. Geoderma 146, 175-182. https://doi.org/ 10.1016/j.geoderma.2008.05.020.

Sehgal, J.L., 2012. Soil Classification. Fundamentals of Soil Science, 2nd edition. Indian Society of Soil Science, pp. 25-60.

Soil Survey Staff, 2014. Keys to Soil Taxonomy, 12th ed. USDA-Natural Resources
Conservation Service, Washington, DC

Verma, R.K., Verma, S.K., 2006. Phytochemical and termiticidal study of Lantana camara var. aculeate leaves. Fitoterapia 77, 466-468. https://doi.org/10.1016/j.fitote.2006. 05.014 .

Verma, M., Sharma, S., Prasad, R., 2009. Biological alternatives for termite control: a review. Int. Biodeter. Biodegr. 63, 959-972. https://doi.org/10.1016/j.ibiod.2009. 05.009.

Villenave, C., Djigal, D., Brauman, A., Rouland-Lefevre, C., 2009. Nematodes, indicators of the origin of the soil used by termites to construct biostructures. Pedobiol. 52, 301-307. https://doi.org/10.1016/j.pedobi.2008.11.003.

Yuan, Z., Hu, X.P., 2012. Repellent, antifeedant, and toxic activities of Lantana camara leaf extract against Reticulitermes flavipes (Isoptera: Rhinotermitidae). J. Econ. Entomol. 105, 2115-2121. https://doi.org/10.1603/EC12026. 